\title{
Rediscovery of a
}

B. Groombridge, E.O. Moll and J. Vijaya

While information was being gathered for Part 1 of the new IUCN AmphibiaReptilia Red Data Book, dealing with crocodilians and chelonians (Groombridge, 1982), it became evident that one small terrestrial emydid turtle, Heosemys silvatica, was known to science by only two museum specimens, both collected in 1911 in hill rain forest in south-west India (Henderson, 1912). The apparent rarity of the species, and the extent to which rain forests in south-west India have been destroyed or modified, led to concern for the species's survival and made a survey of the type locality a matter of priority. The species was included, with 'Indeterminate' status, in the new Red Data Book. This paper is a preliminary report of a brief field survey initiated by the first author and carried out between 26 October and 5 November 1982.

The type specimen of Heosemys silvatica was obtained from Kadar tribals in the vicinity of Kavalai, in the former 'Cochin State Forests', by a collecting party from the Madras Government Museum in 1911 (Henderson, 1912). This specimen was found in dense upland rain forest, at about $450 \mathrm{~m}(1500 \mathrm{ft})$ altitude, in the northwestern slopes of the Anaimalai Hills. The Cochin area, formerly associated with the Madras Presidency, has been incorported into presentday Kerala State since 1956. The origin of the second known specimen of $H$. silvatica is not entirely clear, but it too was almost certainly collected by Kadars in the same general area as the first specimen. A collector from the Madras Museum subsequently dispatched to the area was unable to find any specimens (Henderson, 1912). This species, of an almost entirely aquatic family, was reported to be terrestrial in habits.

The Kadar (or Kadan) have been considered to represent one element among the original preDravidian inhabitants of India (Thurston and Rangachari, 1909; Thurston, 1913), although this in general is difficult to substantiate (Morris, 1982). They are now one of India's many 'Scheduled Tribes', recognised as of special concern. They are a semi-nomadic hill forest people, although some groups have become more settled over the last decades. Still basically hunter-gatherers, they live by the sale or barter of forest produce such as wild honey, spices, resin and bark, and also consume small game such as tortoises and monitor lizards, and grow a few bananas. A typical forest-based group will spend several hours every day in the forest, and Kadars have justifiably been long renowned as experts in 'the ways of the jungle' (Thurston and Rangachari, 1909).

Consultation with staff of the Kerala Forest Department revealed that whatever settlement had existed at Kavalai had been abandoned for several years, but the site of a present Kadar settlement amid hill rain forest in the north-west Anaimalais was indicated. With the kind cooperation of the Forest Department we were able to visit this site. The settlement comprises a riverside forest clearing, about two hectares in extent, with about a dozen Kadar huts scattered among some 


\section{rare Indian turtle}

planted banana trees, flanked by steep forested ridges.

Discussion with the Kadars indicated that they were familiar with two kinds of terrestrial chelonian in their surroundings: the 'valli amai' (= big turtle) or Travancore tortoise Geochelone travancorica, and the 'churel amai' (=cane turtle) Heosemys silvatica. The occurrence of $G$. travancorica was immediately confirmed by the presence in the village of two empty carapaces. discarded after the contents had been eaten. The occurrence of $H$. silvatica was not confirmed until the second of our four days spent searching the forest around the settlement. We had walked for about two hours, up and down two very steep forest-clad ridges, heading for an enclosed valley the guides had suggested was a good site for 'churel amai'. Within five minutes of the party beginning a concentrated search one of our two guides had located a specimen, immobile on the thin layer of forest floor leaf litter, partially concealed by the overhanging branches of ad-

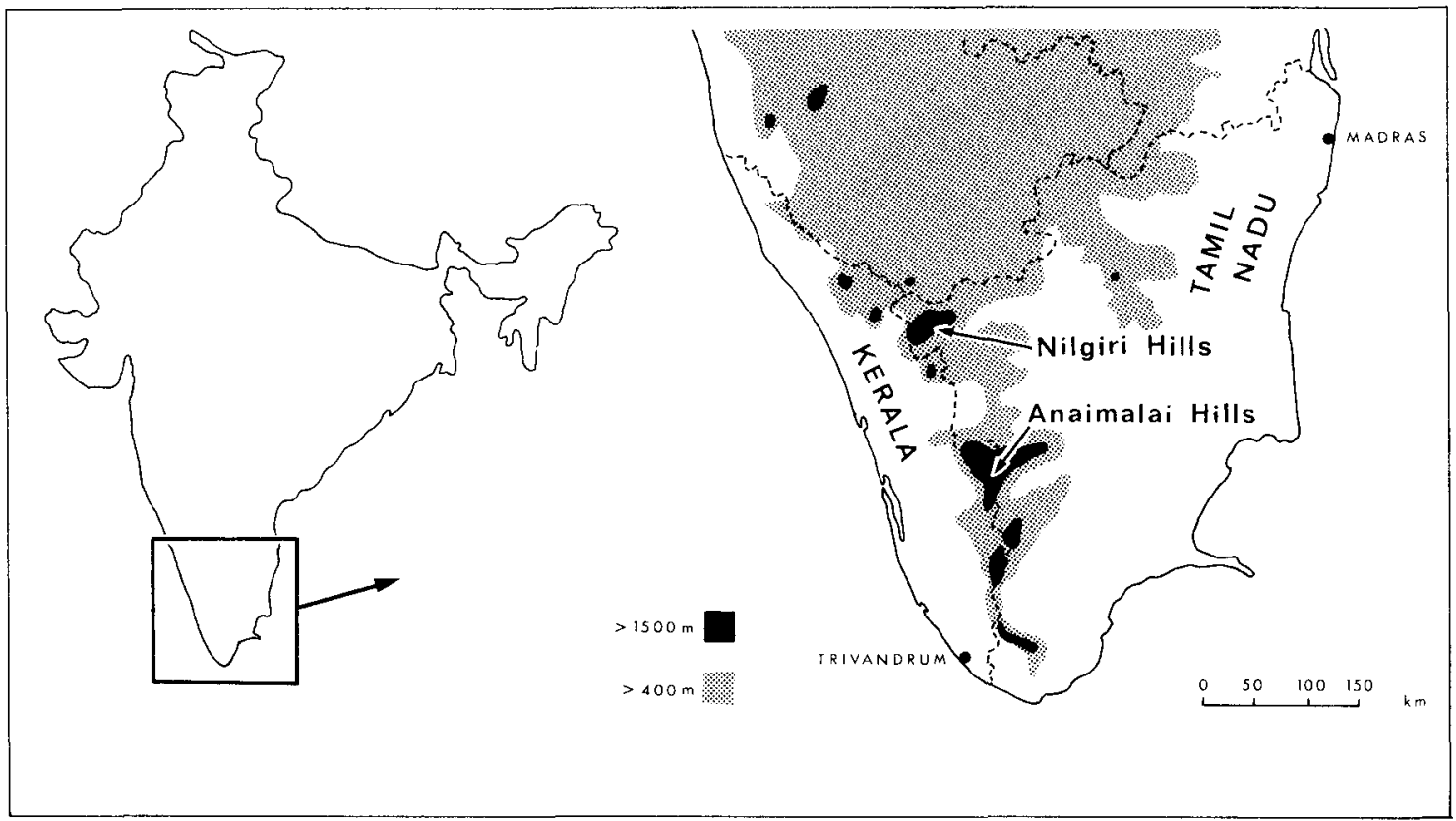

Outline map of India indicating area of South India shown enlarged at right. The latter shows the location of the two hill tracts in the southern ranges of the Western Ghats where the search for the cane turtle was made. 


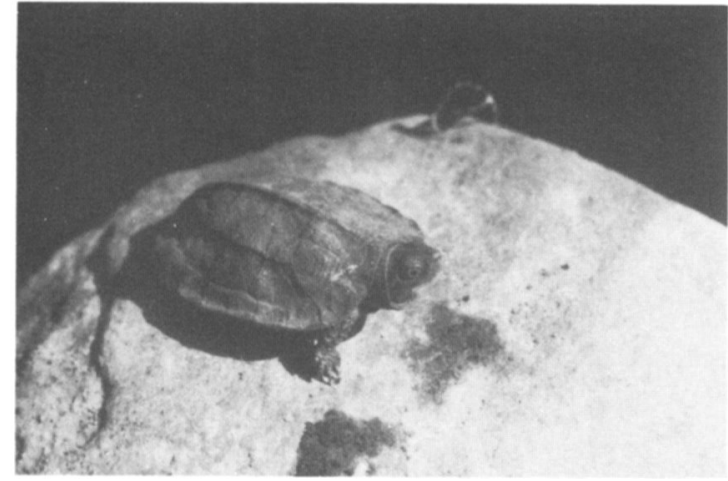

A mature male Heosemys silvatica, the first ever illustration of this species. Note the prominently keeled carapace and absence of webbing between the digits. The carapace length of this specimen (placed on the rock for photographic purposes) is about $11 \mathrm{~cm}$ ( $B$. Groombridge).

jacent shrubs. On a previous visit to the Anaimalais in mid-1982 (Vijaya, 1982) Ms Vijaya had been given a live turtle, the third known specimen of $H$. silvatica, by an inhabitant of a village on the upper Chalakudi River, thus confirming that the species was still extant. However, this memorable occasion near Kavalai was the first time the species had been seen in the wild by anyone other than the local people; the Kadars of course had been as familiar with the species since its scientific recognition as they had presumably been for centuries earlier.

During seven and a half hours spent in this valley, over two days, our party of five persons found ten specimens of $H$. silvatica, equivalent to 0.26 per man-hour. Although far from a direct measure of population density, this figure does give some indication of the relative sparsity of individual distribution. The turtles are very difficult to find, so the species may in fact be less uncommon. Fully grown $H$. silvatica are known to reach only $13 \mathrm{~cm}$ carapace length, are often similar in colour to the leaf litter, and are even similar in carapace shape to many leaf types (one leaf found in some abundance on the forest floor had three prominent longitudinal ribs, matched very closely by the three longitudinal ribs on the carapace of the turtle).

All specimens found were in hill rain forest (apparently unaffected by logging or other 132 clearance), on gentle to steep and rough slopes. on or amidst the floor leaf litter. Although known as the cane turtle by the Kadars, the species did not appear to be especially closely associated with cane clumps (Calamus sp.). Specimens were generally motionless when first seen. although they may already have been disturbed by the observers' presence: the species may be nocturnal or crepuscular. The Kadars who provided the first recorded specimen reported that the turtles inhabit a short underground burrow, not in the vicinity of water (Henderson, 1912); we could not confirm this report. One specimen, kept in a collecting bag overnight, had voided several scutes of a large millipede species commonly seen on the forest floor; possibly terrestrial arthropods in general form a significant part of the diet, although the scutes in question could perhaps have been scavenged as carrion. Henderson's two original specimens subsisted in captivity for several months on an entirely vegetable diet (Henderson, 1912).

Successful reproduction is occurring since our sample of 10 silvatica included animals of various sizes, ranging upward from a very young turtle only about seven $\mathrm{cm}$ carapace length. The species exhibits a very striking sexual, and probably seasonal, dichromatism; male specimens possessed varying degrees of bright red colouration in the iris and on parts of the head. A similar phenomenon has been recorded in only a very few other chelonians, the aquatic asiatic emydid Callagur bormeoensis for example (Moll et al., 1981).

While originally described as a species of Geoemyda, the species was assigned to the genus Heosemys by the last reviewer of the asiatic Emydidae (McDowell, 1964), however 'Heosemys' silvatica was apparently not examined. The remaining four species of the genus occur in south-east Asia, west to Burma. Preliminary examination of live specimens suggests that this taxonomic assignment may be inappropriate; further study may reveal an entirely different pattern of relationships.

We were subsequently also able to obtain live specimens of $H$. silvatica (being kept for food) from Kadars at a village further down the Chalakudi from the site where Ms Vijaya had previously been given a specimen, and we learnt Oryx Vol 17 No 3 
of skeletal material having been obtained from a site north of Kavalai.

It should be stressed that localities where populations of $H$. silvatica have been confirmed are areas of hill rain forest, apparently primary forest (at least at our study site), within relatively few kilometres of each other in the western fringes of the Anaimalai Hills. None of these localities are within a protected area of any kind.

Although there appear to be no immediate threats to the species, the extent to which the rain forest in south-west India has been cleared, logged or otherwise modified, is a cause for serious concern (Mani, 1974; Saharia, 1981). For example, there are now extensive teak and rubber plantations along much of the Chalakudi River; very little rain forest is seen until the uppermost course of the river is reached.

Although immediate fears for the species's survival have receded with the rediscovery of wild populations, it appears likely that these populations could not withstand any modification of their habitat. The long-term survival of the species in the wild will, to the extent that it is limited to primary rain forest, depend on the long-term survival of adequate areas of undisturbed forest. For this reason it is important to establish to what extent the apparently suitable habitat in the southern ranges of the Western Ghats is actually inhabited by $H$. silvatica. There are still large areas around Kavalai and other parts of the Anaimalais to be investigated, also areas further north around the Nilgiri Hills, and further south in the Cardamom Hills and other hill ranges. No specimens were found in the Nilambur Valley, in the northwest Nilgiris, during a day visit in November 1982. Similarly, it is important to establish whether the species occurs in any of the existing protected areas affording potentially suitable habitat. There is a possibility that the species may be present in Parambikulam Wildlife Sanctuary (Kerala), around the headwaters of the Chalakudi River (Vijayan, 1978), several kilometres east of our study site. Other sites requiring investigation include the Mundanthurai Sanctuary (Tamil Nadu), Eravikulam Rajamalai Park (Kerala), and the proposed Silent Valley National Park (Kerala). No specimens of $H$. silvatica were found during a recent Zoological Survey of India investigation of Silent Valley.

Rediscovery of a rare Indian turtle

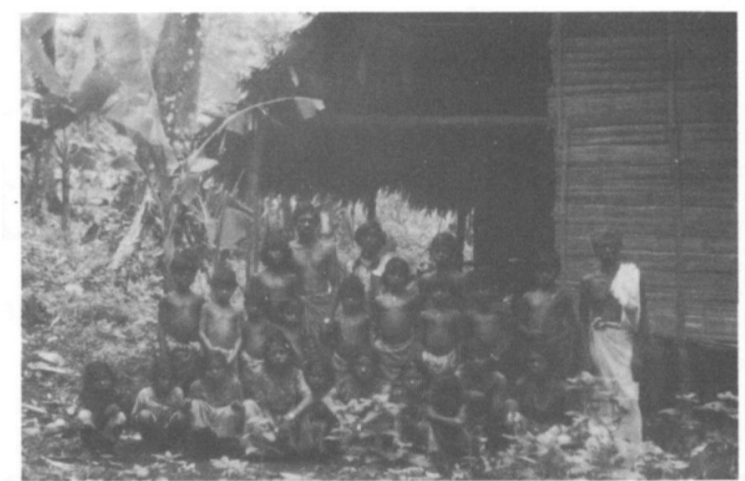

A group of Kadar - a semi-nomadic hill forest people who are familiar with Heosemys silvatica as part of thier diet ( $B$. Groombridge)

At our study site the terrestrial emydid $H$. silvatica was sympatric with the testudinid Geochelone travancorica, the Travancore tortoise. This latter is a more widespread, but apparently declining species, occurring in hill forests from the Coorg region of southern Karnataka southward along the Kerala-Tamil Nadu border uplands. It is listed 'Insufficiently Known' in the Red Data Book (Groombridge, 1982). A total of six live specimens were found at this site, a frequency of 0.16 per man-hour. This suggests a relatively low density, and the species is in general clearly under pressure due to habitat loss and possibly human predation. Both these chelonian species appear to provide a valuable protein source for the Kadars, and $G$. travancorica is also utilised by the Hill Pandaram, a forest tribe living in the Pandalam Hills south of the Periyar River (Morris, 1982). The Indian monitor lizard Varanus bengalensis is eaten, as well as the chelonians, when obtainable. It would be of value to quantify the contribution made by reptiles to the diet of the hill forest tribes, and to determine what area of forest is necessary to support the requisite reptile biomass, with regard to long-term utilisation of this resource.

Rain forest vegetation occurs in mainland India in high rainfall zones in the extreme north-east, and in the south-west, along the southerly portions of the Western Ghats, especially the windward slopes (Mani, 1974). Many taxa in the south-west are clearly related to taxa in the north-east forests and in other parts of south-east Asia. However,

133 
there is notably high endemicity in the flora and fauna of the south-west Indian forests, and the region has been recognised as a distinct biogeographic province-the Malabar Province (Udvardy, 1975). Although some of the larger mammals endemic to this region, such as the Nilgiri tahr Hemitragus hylocrius (in high altitude grassland), Nilgiri langur Presbytis johni, and liontailed macaque Macaca silenus, have benefitted from significant research and conservation effort, the so-called 'lower vertebrates' have received virtually no attention. The importance of the south-west forests in terms of amphibian and reptile diversity is not widely enough appreciated. For example, there are approximately 35-40 endemic amphibian species, including five endemic genera, two of them monotypic. The bufonid Pedostibes tuberculosa and the microhylid Melanobatrachus indicus are just two of many rare and unusual amphibians requiring field research; only one specimen of the former has been seen (Pillai, 1982) since the species's description in 1875 . There is similarly high endemicity and morphological distinctiveness among the snakes and lizards. One family of over 40 species of burrowing snakes, the Uropeltidae, is restricted to south-west India and Sri Lanka. As with the chelonians, most scientific collecting and descriptive work on these groups was carried out around the turn of the century. It should be recognised that we have only a first approximation of the actual number of biological species and their true distribution areas.

Recent work by the Zoological Survey of India (Southern Regional Station) and the Madras Snake Park has improved our scientific knowledge of the south-west forest herpetofauna, but very much remains to be done, and it is important that it is done in the near future. The urgency of the task is made only too clear by a report from Rom Whitaker (Chairman, IUCN Snake Specialist Group); he comments (Whitaker, 1982) that the wooded sholas in the Palni Hills have changed almost beyond recognition in the last 30 years, but recently in the remnants of Tiger Shola his three-year-old son turned over a rock to reveal the first specimen of a hitherto unknown species of kukri snake Oligodon sp.

It is to be hoped that the rediscovery of Heosemys silvatica, and future research on the species 134 planned by Ms Vijaya and others, will further demonstrate the herpetological importance of the Malabar region. and provide a new impetus for work on the amphibians, snakes and lizards.

\section{Acknowledgments}

This project could not have been performed without the generous cooperation of officials of the Kerala Forest Department, notably Mr G. Mukundan (Additional Chief Conservator of Forests), Mr R. Nair (Conservation of Forests, Trichur District) and $\mathrm{Mr}$ Joseph (Divisional Forest Officer, Chalakudi Division of Trichur District). The first author is also extremely grateful to the People's Trust for Endangered Species for providing the vital financial support. The work of the second author is being supported by an Indo-American Fellowship and a grant from the Animal Research and Conservation Center of the New York Zoological Society.

\section{References}

Groombridge, B. 1982. The IUCN Amphibia-Reptilia Red Data Book. Part 1. Testudines. Crocodylia. Rhynchocephalia. IUCN. Gland (Switzerland).

Henderson. J.R. 1912. Preliminary note on a new tortoise from south India. Rec. Indian Mus. 7, 217.

Mani. M.S. (Ed.) 1974. Ecology and biogeography in India. Monographiae Biologicae 23. W. Junk. The Hague.

McDowell. S.B. 1964. Partition of the genus Clemmys and related problems in the taxonomy of the aquatic Testudinidae. Proc. zool. Soc. Lond. 143 (2). 239-279

Moll. E.O. Matson, K.E. and Krehbiel, E.B. 1981. Sexual and seasonal dichromatism in the Asian river turtle Callagur borneoensis. Herpetologica 37 (4). 181-194.

Morris, B. 1982. Forest Traders. A Socio-economic study of the Hill Pandaram. London School of Economics Monographs on Social Anthropology, No. 35. Athlone Press, New Jersey.

Pillai. R.S. 1982. In litt. 25 February.

Saharia. V.B. 1981. Wildlife in India. Ministry of Agriculture, Government of India.

Thurston. E. 1913. The Madras Presidency, with Mysore, Coorg and the Associated States. In series. Provincial Geographies of India. (Ed. T.H. Holland). Cambridge University Press.

Thurston. E. and Rangachari. K. 1909. Castes and Tribes of Southerm India. Vol. VII. Government Press, Madras.

Udvardy. M. 1975. A classification of the biogeographical provinces of the world. IUCN Occasional Paper No. 18.

Vijaya, J. 1982. Rediscovery of the Forest Cane Turtle (Heosemys siluatica) of Kerala. Hamadryad 7 (3). 2-3.

Vijayan, V.S. 1978. Parambikulam Wildlife Sanctuary and its adjacent areas. J. Bombay nat. Hist. Soc. 75 (3). 888-900.

Whitaker. R. 1982. Introduction: aims and objectives of the Snake Specialist Group. Proceedings of the IUCN/SSC Snake Group. First Meeting. 8-12 November 1982. pp. $1-4$.

B. Groombridge. Conservation Monitoring Centre. 219(c) Huntingdon Road, Cambridge CB3 ODL, UK.

E.O. Moll. Department of Zoology. Eastern Illinois University. Charleston. Illinois 61920, USA.

Ms J. Vijaya. Madras Crocodile Bank. Vadanemmeli Village. Perur Post Office. Mahabalipuram Road. Chingleput District. Tamil Nadu. India. 